\title{
Meat production, consumption and marketing tradeoffs and potentials in Ethiopia and its effect on GDP growth: a review
}

\begin{abstract}
Meat and other slaughter by-products being exportable food items have been contributing to the foreign export earning and GDP growth of Ethiopia since the beginning of meat processing. Even though the country is blessed with huge livestock resources, the share of meat and other slaughter by-products exported from the overall export commodities is not more than $2 \%$ and the percapita meat consumption is below the average of Sub-Sahara African countries. This study was therefore, implemented to review the potentials and tradeoffs of meat production, processing and marketing in Ethiopia and seeking strategic intervention options to unleash the potentials after reviewing the available national and international resource materials. The study therefore indicated that, as opposed to Ethiopia's strategic location to market and sound climatic condition, the country is not benefiting from the huge livestock resources due to knowledge gap; limited compliance to meet the international requirements including food safety standards like ISO, GMP and HACCP; limited promotion done in marketing; limited intra-Africa trade integration; poor linkage among stakeholders; few market outlets and other interlinked problems. On top of these meat consumption trends is almost stagnant and the calorie intake per capita from meat is in a declining state. Therefore, policy support in terms of diverse incentive mechanisms; encouraging more research and development work so as to benefit smallholder farmers, pastoralists and processors and the need for traceability and residue monitoring, market promotion and conducting benchmarking and twinning programs are some of the measures to be taken in order to be competitive in the global market. Better business communication with potential buyers and back and forth linkage with stakeholders along the value chain is also very important for the transformation of the sector from the current staggering stage to globally competitive agribusiness.
\end{abstract}

Keywords: challenges, meat, potentials, traceability, tradeoffs
Volume 8 Issue 3 - 2018

\author{
Tekeba Eshetie,' Kelifa Hussien,' Tadesse \\ Teshome,' Abebaw Mekonnen² \\ 'Ethiopia Meat and Dairy Industry Development Institute \\ (EMDIDI), Ethiopia \\ ${ }^{2}$ Ethiopia Meat Producers- Exporters Associations, Ethiopia
}

Correspondence: Tekeba Eshetie, Ethiopia Meat and Dairy Industry Development Institute, PO box 1573, Bishoftu, Ethiopia, Email tekebanega@gmail.com

Received: February 02, 2018 | Published: May 01, 2018

\section{Introduction}

Continued its buoyancy, the Ethiopian economy has registered a significant growth rate of 10.3 percent in 2013/14, which was about double growth as compared to the 5 percent growth for SubSaharan Africa for the year 2014..$^{1-3}$ This makes Ethiopia one of the fast growing economies not only in Africa but also at global level. Sector wise, Agriculture which is the main stay of the economy grew by 5.4 percent while industry and services expanded by 21.2 and 11.9 percent, respectively revealing the fact that the economic growth in Ethiopia has turned to become broad based and start transforming. ${ }^{3,4}$ The percentage share of GDP by major economic sectors in the year 2010/11 was 44.7 for Agriculture, 10.5 for Industry and 45.5 for the Service sector but these figures changed to $38.5,15.1$ and $46.3 \%$ in the year 2014/15 in the same order. ${ }^{5}$

At a national level, livestock is the source of industrial raw materials (milk, meat, hides and skin) and high value protein to potential consumers in Ethiopia $[1,6]$. It also contributes about $45 \%$ to the Agricultural GDP, $18.7 \%$ to the national GDP and $16-19 \%$ to the total foreign exchange earnings of the country. ${ }^{6-9}$ Because of low productivity and poor management systems practiced however, the average live weight of cattle is estimated at $250 \mathrm{~kg}$; with $14 \%$ off take rates and $110 \mathrm{~kg}$ carcass weight at $44 \%$ dressing percentage. ${ }^{1,8}$ The off take rates for sheep is $40 \%$ that of goats $27 \%$ with $10 \mathrm{~kg}$ and $8 \mathrm{~kg}$ of carcass weight, respectively ${ }^{8,10}$
Having diverse livestock resources to gather with its strategic location, Ethiopia has got more advantage to market livestock and livestock products to wider parts of the world than most African countries. ${ }^{1,6}$ But out of all live animal export in the country (85\%) is illegal ${ }^{1,11}$ to Djibouti, Somalia, Kenya and Sudan. On the other hand, the major and formal meat export destination from Ethiopian export abattoirs for chilled small ruminant meat is limited to United Arab Emirates and Kingdom of Saudi Arabia with the order of $60 \%$ and $38 \%$ share. ${ }^{1,10,12,13}$ The meat by-products for export include, intestine, testis, liver, brain, lung, kidney and abomasums which are mostly exported to Vietnam, Saudi Arabia, Egypt etc. ${ }^{14}$

The rest of meat is exported to some North African countries and other Arabic countries. ${ }^{1}$ The contribution of meat and meat byproducts export to GDP is growing but not to its potential as it is observed in a number of reports. On the other hand, there are more than 300 local abattoirs which produce meat for local consumption at different locations with different capacity and facilities but with no standards.

However, the export of meat on both shoat and beef origin were not without challenges in Ethiopia. Therefore, this review study is initiated to identify the major challenges and potentials of meat production, trade and consumption from Ethiopia compared to some African countries and to propose possible intervention areas to leverage its potential. 


\section{Meat consumption and import- export dynamics from African perspective}

According to report, ${ }^{15}$ at present Africa remains a relatively small player in global export market for meat products. In Africa, in recent years, annual meat production from ruminants was 7.5 million tonnes, of which $65 \%$ was from cattle, $32 \%$ from small ruminants and 3\% from Camelids. ${ }^{16}$ The report further indicated that, the African continent accounts for about $4 \%$ of the world production of animal products and its share in world trade in animal products is less than $1 \%$ and its meat consumption (kcal/capita/day) between 1961-2007 is not at its progressive state as indicated in Figure 1.

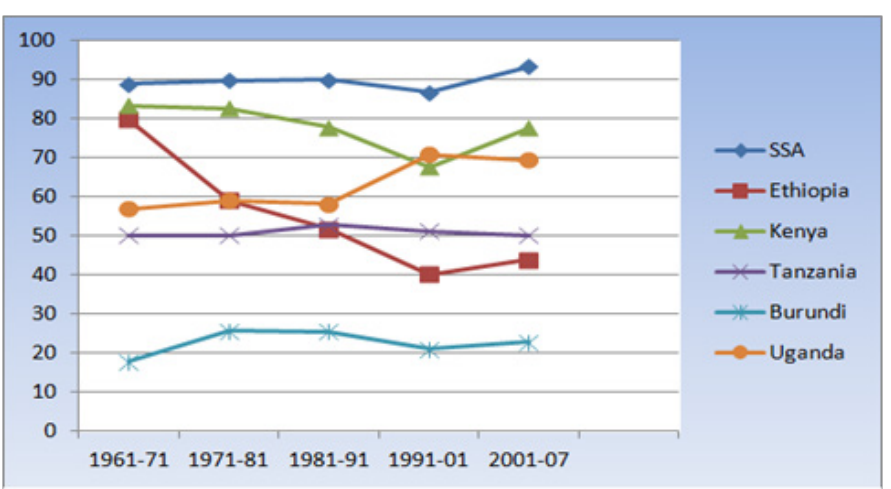

Figure I Meat consumption (kcal/capita/day) for some selected SSA countries. Source: Compiled from. ${ }^{17,18}$

As this figure indicated, some of the countries in the list like Uganda, Burundi and SSA, the per capita calorie consumption from meat is in the increasing trend where as for Ethiopia there is a sharp decline may be due to high population growth as opposed to very limited meat access. For the remaining countries listed, the per capita kcal intake from meat consumption is almost constant across the years.

In terms of live animals, Africa is generally self sufficient and is indeed a net exporter. Nevertheless, it remains a net importer of animal products, while the same time the opportunities for intra-African trade are not fully exploited. The majority of African countries import animal products from other continents and Africa exports of animal products go mostly to developed countries. ${ }^{15}$ To reverse this trend, to the benefit of the African continent, there is now a need to promote inter-African trade. According to ${ }^{15,19}$ Ethiopia has imported significant amount of meat from the United States of America, United Arab Emirates, Italy, The Netherlands, China and South Africa. In Ethiopia, in addition to export-oriented industrial development strategy, significant emphasis was also given to promoting efficient import substitution industrialization; however the country is still dependent on foreign import as indicated in Figure 2. When we see the unit price of a kilo of fresh beef exported from Ethiopia mainly to the Middle East countries is a maximum of 4 USD where as the importing price from South Africa for fresh beef is sold to the extent of 10.33 USD which needs a study at the end market and the whole value chain.

When it comes to exports of beef, chicken and game animals meat, the overwhelming majority of products come from Southern Africa, notably South Africa, Botswana and Namibia. Goat and pig meat exports are derived predominantly from East Africa, while sheep meat exports come from Northern Africa, mainly Sudan. If we look at imports of meat, Africa is similarly a small player in global markets, although in aggregate the value of imports of meat products is larger than that of exports. ${ }^{15}$

Globally, imports of meat products from developing market are on the rise and provide the potential impetus for new suppliers, including those in Africa.$^{20}$ The ability of Africa to take advantage of these new opportunities will depend largely on its ability to compete effectively with other global competitors. But Africa including Ethiopia faces a number of challenges in its bid to become more integrated into other global meat export markets due to issue of limited competitiveness with other diverse competitors. ${ }^{15}$

A major development in global meat markets that has an impact on Africa, both as an exporter and importer, has been the rise of Brazil as an important global player in meat exports, notably beef and chicken. According to the ${ }^{21}$ Brazil exported US \$ 3 Billion in 2006 from fresh and frozen beef alone but before 4 years the figure for similar products were US \$ 1.2 Billion. Similarly in chicken ${ }^{21}$ revealed that exports from Brazil rose from US \$ 1.9 Billion in 2003 to over US\$ 3 Billion in 2006. At present, Brazil manages to export to over 60 countries worldwide. The emergency of Brazil and India in Global meat markets has important ramifications for Africa, both as exporter and an importer. The effect of meat export and import from and to Africa has got its own effect on the percapita meat consumption as indicated in Figure 3.

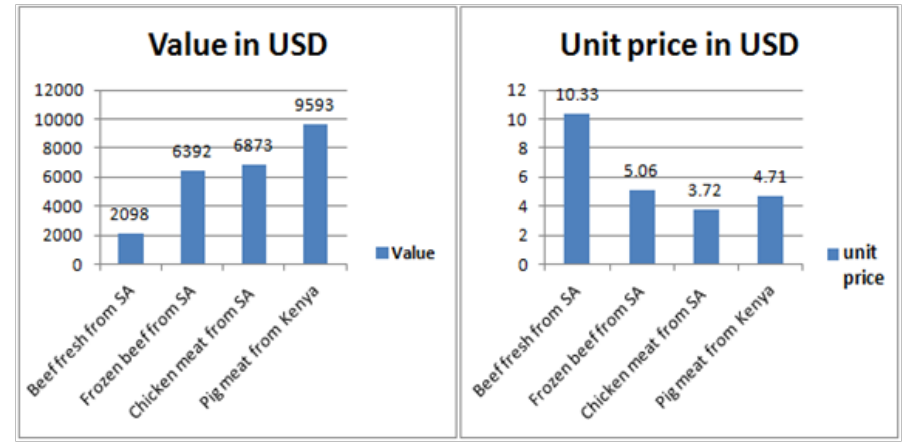

Figure 2 Import of different meat types from different countries to Ethiopia in 2006 (in USD).

Source: Compiled from. ${ }^{15}$

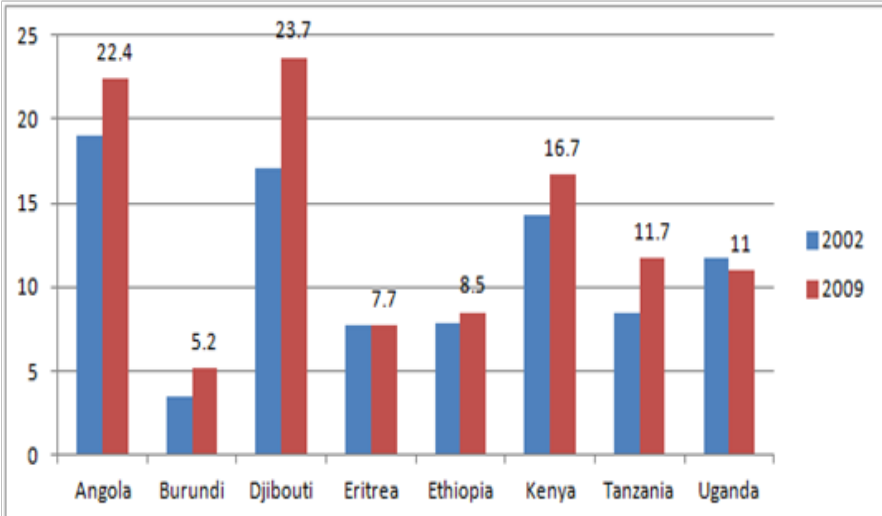

Figure 3 Per capita meat consumption of Ethiopia compared to some selected African peers.

Source: Compiled from. ${ }^{17}$ 
Even with this abundance of livestock and meat resources, the only countries which Ethiopia better off are Burundi and Eritrea. According to ${ }^{20,22}$ report, there are several reasons for this low meat consumption, including low per capita income, high domestic meat prices and the fasting days by the Orthodox Christian which lasts for at least 200 days in a year that reduces the aggregate demand by $20-35 \%{ }^{23,24}$. However, the domestic meat demand is believed to increase with increasing literacy and family income. ${ }^{25}$ But the global figure for some selected countries indicated that, the correlation between high income and increase per capita meat consumption is not strong enough for some countries to justify the effect of income on meat consumption and sometimes even the opposite is observed as indicated in Figure $4 \&$ Figure 5 for per capita meat consumption and GDP growth, respectively.

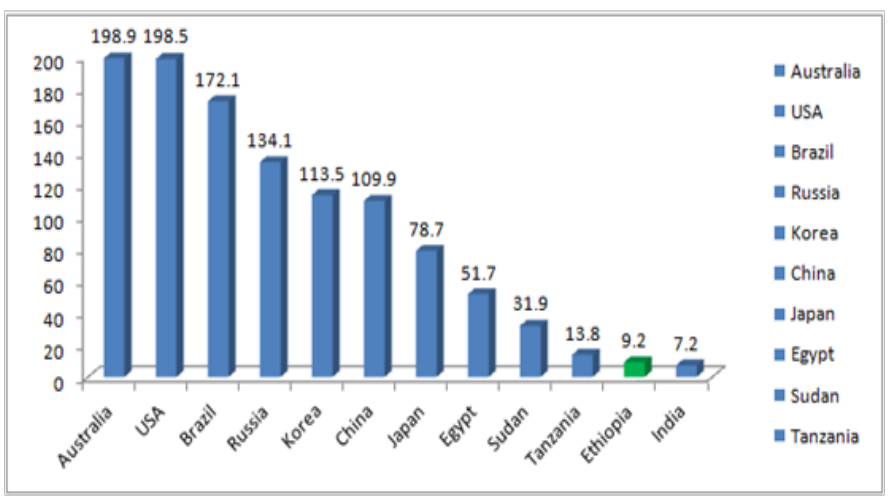

Figure 4 Per capita meat consumption for selected 12 countries (Lb/per capita).

Source: From. ${ }^{26}$

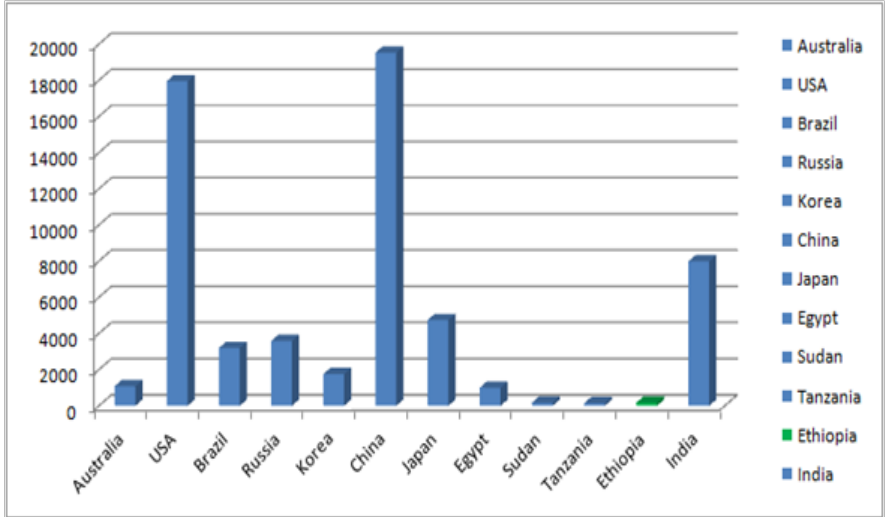

Figure 5 Gross Domestic Products (GDP), 2015 PPP in Billion USD for selected 12 countries.

Source: From. ${ }^{26}$

From these two figures, it is clear that in addition to increasing wealth, the tradition and culture for meat consumption of the people of each particular country seems to have effect on the per capita meat consumption. For example, in Figure 4, the per capita meat consumption for Australia is 198.9 pounds where as its GDP in Billion USD for PPP is 1082. On the other hand, the per capita meat consumption for India is not more than 7.2 pounds but the GDP in Billion USD for PPP is 7982 as indicated in Figure 4 \& Figure 5. These figures also vary for other countries in the list even though the relation varies from one country to the other.

\section{Trends of meat export and other products from Ethiopia and its productivities}

Ethiopia has huge livestock wealth inventory in the world. ${ }^{1,20}$ However, the country current share in the global export market for meat is quite small. ${ }^{20,27}$ In 2011, the volume of global meat export was estimated at USD 105 Billion, from this value Ethiopia accounted for less than one percent of this total, of which most is chilled goat meat followed by sheep meat. ${ }^{28}$ There are many reasons for these which include but not limited to very low off take rates; large number of animals that by-pass abattoirs and are exported live both illegally and legally. It is also seen that producers who are not commercially oriented and sell only in need of cash or when draught affects the environment or when their animals getting too old and other limiting factors such as failure in meeting the international standards by meat processors. ${ }^{1,20}$

Almost all the existing abattoirs in Ethiopia have facilities for goats and sheep but facilities for cattle are mostly limited for local consumption and few abattoirs start export of beef recently [19 and personal observations]. On the other hand, beef production figures suggest that Ethiopia produces almost 13 times or $93 \%$ more beef than Botswana and $94 \%$ more hides. However, the increased meat production which may be observed in Ethiopia has been largely attributed to increased livestock numbers rather than improved productivity. ${ }^{29}$

Based on cold dressed weights, for livestock slaughtered in abattoirs, Ethiopia has been classified as one of the lowest in the world, with carcass weights averaging $110 \mathrm{~kg} / \mathrm{head}$ for cattle, $10 \mathrm{~kg}$ / head for sheep and $8 \mathrm{~kg} /$ head for goats, all of which are below the average productivity of all least developed countries. ${ }^{8,30}$ Although Botswana has fewer beef animals than Ethiopia, it produces superior carcasses averaging $190 \mathrm{~kg}$ cold dressed weights for traditional cattle and $230 \mathrm{~kg}$ cold dressed weight for commercial and feedlot cattle. ${ }^{29}$ Inferior carcasses from agro-pastoral and pastoral systems in Ethiopia can be attributed to many important factors including and not limited to low genetic potential for indigenous cattle, prolonged nutritional stress, overstocking which leads to overgrazing and heavy parasite burdens etc. ${ }^{29,31}$ On the other hand, meat being one of the few export commodities in Ethiopian has been contributing little but it is still in a rise $^{27,32-34}$ as indicated in Figure 6.

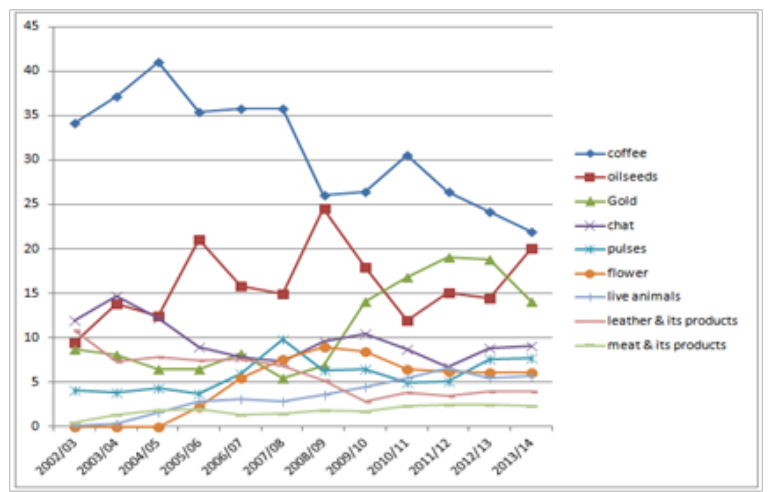

Figure 6 Meat and its products position from Ethiopian export commodity list.

Source: Calculated by the authors from. ${ }^{33,34}$

Considering the resource base and other comparative marketing advantages of Ethiopia, the export volume to the middle east countries 
has been low as compared to other competitors. ${ }^{1}$ However, as most reports including Ethiopian Custom Authority indicated, the volume of small ruminants meat and live animals export is growing in recent years but the increase in export of meat is mainly due to the number of new export abattoirs joining the sector rather than improving the productivities of individual abattoirs (personal observation). In 2013/14 alone, Ethiopia exported nearly 675,874 live animals and 15,704 tones of chilled carcass meat from goat and sheep which totally worth of 242. 5 million USD. ${ }^{13}$ The major competitors of Ethiopia for the Middle East market include Australia, Brazil, India, Pakistan, Argentina, New Zealand, and Iran. ${ }^{1}$ The relative performance of meat export to the other livestock products export from Ethiopia during the first Growth and Transformation Plan (GTP) is indicated in Figure 7. As it can be seen from the figures, meat is a dominant export commodity with average share more than $92.5 \%$ of all.
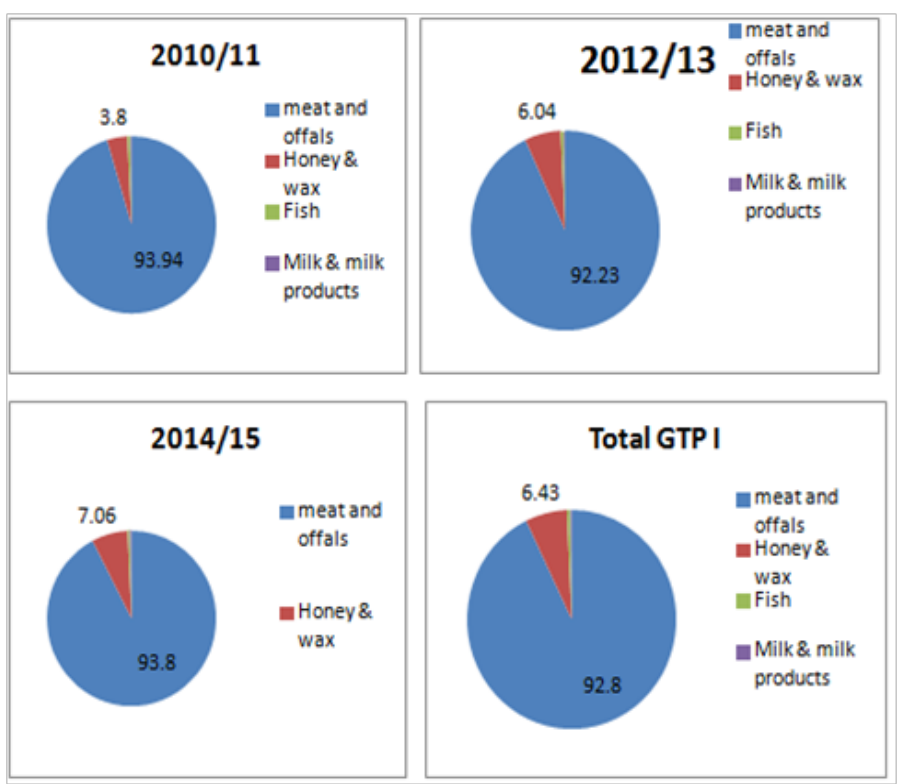

Figure 7 Percent share of livestock products export in Millions of USD during GTP I period.

Source: Compiled from different source by the authors

\section{Opportunities of ruminant meat export market from Ethiopia}

Large and small ruminant population with diverse genotypes

a) Proximity to the middle East market

b) High Government support and interest at all levels

c) The coming in to being of Integrated Agro-industrial park in Ethiopia at strategic locations to give one stop shopping service and to harmonize the products from the development wing with manufacturing

d) Increasing number of export abattoirs in Ethiopia with big investment opportunities

e) The beginning of livestock registration and traceability systems at pilot level

f) The coming into being of Livestock and Fishery Development Ministry in Ethiopia g) The interest to Ethiopian meat observed from Chinese government side and other countries

h) The presence of meat strategy and Livestock Master Plan studies as guiding documents

i) The consensus reached among most African countries for intraAfrican integration which will open the new avenue for trade relationship

j) The fast and sustainable economic growth which has got a spillover effect for the development of the manufacturing sector including the meat sub-sector

\section{Binding constraints for meat export}

i. Inability to penetrate huge export markets and maintain substantial market shares

ii. Inefficient and non-transparent livestock marketing systems

iii. Lack of capacity for cattle slaughtering facilities, in cold chain maintenance, processing, packaging of export quality meat and meat products

iv. Shortage of consistent and competitive supply of slaughter animals which meet quality requirements mainly for export market

v. Limited coverage of research and development interventions on the sector

vi. The presence of immature livestock traceability and livestock registration systems in the country

vii. Illegal cross boarder livestock trade

viii. Subsistence farming system (not commercial oriented)

ix. Limited skill to handle the challenges in the sub-sector

$\mathrm{x}$. Limited compliance to the international market requirements

\section{Conclusion}

This study tried to single out the potentials and tradeoffs of Ethiopian meat production, marketing and consumption phenomena and suggested some improvement intervention areas for the sector. As to the production of meat, the majority of meat is produced by smallholder farmers and the pastoralists in the country. The meat produced per animal is very low as compared to the African peers due to the poor genetic background of the animals, under developed management system including feed supply, health service etc.

The poor market linkage including limited Intra-African trade integration and information system and the failure to comply with the international standards and market requirements are other bottle necks to the sector. On the other hand, the coming into being of integrated agro-industrial park to deliver one stop shopping services, the presence of guiding development strategies for the sector, the continues support of Ethiopian government to the sector including export incentives, Ethiopian strategic location to the terminal market, the commitment of the government in developing the infrastructure include road net work and other efforts of the government to make Ethiopia as a power house for the region will be a good opportunities for the committed investors. 
Similarly, the tradeoffs mentioned above at some point will serve as opportunities for new investment in the country. Therefore, by addressing the technical constraints indicated in this report and taking advantage of the opportunities and potentials attached to them, the meat processing value chain development should be the focus area by joint efforts of the government and private investors along the value chain.

\section{Recommendations}

Based on the findings from this study and personal observations, the meat export performance in Ethiopia is in the increasing trend but not as to the potential. So the following recommendations are made to develop the sector along the value chain.

a) Promotion of exports to more remunerative markets through the introduction of a practical and affordable system of animal identification and traceability,

b) Development of programs to ensure food safety and animal health through monitoring of abattoirs and disease surveillance and implementation of SPS requirements

c) Harmonizing the efforts of different stakeholders including the regulatory body, facilitators and researcher, logistics operators, marketing, development wing etc.

d) Applications of existing recommendations in the livestock master plan study and different meat development strategies in the country for skill development, experience sharing and application of twinning arrangements with potential countries

e) Establishment of Quality based standards and pricing of meat products including live animals

f) Work on illegal livestock trade and develop the local market information system

g) Development of the infrastructure close to meat processing premises

h) Encouragement of modern ranching system and feed lot operations for sustainable livestock supply and products traceability

i) Branding of the Ethiopian meat and breed of origin

j) Facilitating and supporting participation of export operators at strategic trade fares in end and domestic markets

k) Encouraging and capacitating meat producers-exporters to fabricate beef and export in frozen and different value added forms

1) Encourage the private sector through incentive packages to render livestock transport services using designated trucks to reduce cost of transport; enhance quality and improve animal welfare

m) Popularize vertical integrated large scale beef industry development by incorporating commercial feed production, processing, ranching, transporting, beef fabrication and market operations

n) Inter-regional trade integration with COMESA, IGAD and other East Africa member states

o) Standardization and capacity building of local abattoirs to produce meat to the standard and to grow to export level.

\section{Acknowledgments}

Author declares no acknowledgment.

\section{Conflict of interest}

Author declares no conflict of interest.

\section{References}

1. USAID. End market Analysis of Ethiopian Livestock and Meat. 2010.

2. Ethiopia's Great Run: the Growth Acceleration and How to Pace it. World Bank Group, 2014.

3. NBE. National Bank of Ethiopia Annual Report. 2014.

4. DAB Development Research and Training PLC. An overview of Ethiopian Manufacturing Sector. Addis Ababa Chamber of Commerce and Sectoral Association. 2015.

5. National Planning Commission. Growth and Transformation Plan II. Volume I: Main text. 2016.

6. FAO. Analysis of price incentives for live cattle in Ethiopia or the time period 2005-2012. 2015.

7. Kefyalew A, Tarkegne A. Meat and live animal export in Ethiopia: Status, challenges and opportunities. Global Advanced Research Journal of Food Science and Technology. 2013;2(4):054-059.

8. MoA (Ministry of Agriculture). Annual Report of Ministry of Agriculture, Ethiopia. 2012

9. Yebchaye D. Evaluation of chilled goat carcass quality along the cold chain loaded from two export abattoirs in Ethiopia. 2014.

10. ESGPIP (Ethiopian Sheep and Goat Productivity Improvement Program). Export requirements for meat and live small ruminants. Technical Bulletin. No. 47. 2011

11. Abebe B, Zelalem Y, Zerihun A, et al. Livestock and livestock products and by-products trade in Ethiopia. 2016;6(7).

12. Hailemariam T, Getachew L, Dawit A. Market structure and function for live animals and meat exports in some selected areas of Ethiopia. Research report 79. 2009.

13. ERCA (Ethiopian Revenues and Custom Authority). Ethiopian Revenues and Custom Authority Annual Report. 2015.

14. Harko Halala. Review of beef cattle value chain in Ethiopia. College of Agriculture, Wolaita Sodo, University, Ethiopia. 2015;5(7).

15. Karl M Rich. What can Africa contribute to global meat demand? Opportunities and constraints. Outlook on Agriculture. 2009;38(3):223233.

16. Mankor A. Promoting Intra-Africa Trade in Animal and Animal products. OIE conference. 2013.

17. FAOSTAT (Food and Agricultural Organization Statistics). FAOSTAT Data base. 2015.

18. Nicolas DC, Francis M, Guido P. Food production and consumption trends in Sub-Saharan Africa: Prospects for the Transformation of the agricultural Sector. Working Paper United Nation Development Program. 2012.

19. Yesihak YM, Edward CW. Carcass quality audit-A strategy to improve beef sector in Ethiopia. African Journal of Agricultural Research. 2015;10(28):2731-2737. 
20. Addis Ababa, Science and Technology University (AASTU). Ethiopian Agro-industry Strategy Meat Industry Sub-sector Strategic Plan 2016. 2016 .

21. UN Comtrade Report United Nations.

22. AACCSA (Addis Ababa Chamber of commerce and Sectora Associations). Value chain Study on Meat Processing Industry in Ethiopia. 2015.

23. Aleme A, Lemma Z. Contribution of Livestock Sector in Ethiopian Economy: A review. Advances in Life Sciences and Technology Journal. $2015 ; 29$.

24. UNDP (United Nation Development Program). Policies to accelerate Investment and Growth of Industrial Sub-sectors of Ethiopia final report. 2017.

25. Shapiro BI, Gebru G, Desta S, et al. Ethiopia Livestock Master Plan ILRI Project Report. Nairobi, Kenya; 2015.

26. OECD (Organization for Economic Co-operation and Development). Meat consumption indicator report. 2015.

27. Birhanu. Determinants of Ethiopia's Export Trade. Africa Economic Research Consortium, Addis Ababa, Ethiopia; 2016.
28. USAID (United States Agency for International Development). Agricultural Growth Program, Agribusiness and Market Development (AGP-AMDe) Project. Submitted by ACDI/VOCA to Contracting Officer'Representative Tewodros Yeshiwork, USAID Ethiopia.; 2012.

29. Economic Commission for Africa Eighth Session of the Committee on Food Security and Sustainable Development. Report on Livestock value chains in Eastern and Southern Africa: A regional perspective. 2012.

30. MoST (Ministry of Science and Technology in Ethiopia). Agro Processing Sector Meat Industry National Science \& Technology Innovation Road map (2016-2026). 2016.

31. Arend Jan Nell. Quick scan on the livestock and meat sector in Ethiopia Issues and opportunities. Wageningen University, The Netherlands; 2006.

32. Behnke R, Metaferia F. The contribution of livestock to the Ethiopian economy-part II. IGAD LPI Working Paper 02-11. Addis Ababa, Ethiopiai: IGAD; 2011

33. CSA (Central Statistical Authority). Report on the 2nd Quarter of the 2016 Manufacturing Business Survey, Addis Ababa, Ethiopia; 2016

34. National Bank of Ethiopia (NBE) reports. Determinants of Ethiopian export trade share. 2016 